\title{
Economic profitability in conventional and irrigated coffee production systems in three municipalities in the Marilia region of São Paulo, Brazil
}

\author{
Patrícia Helena Nogueira Turco ${ }^{1^{*}}$ Maura Seiko Tsutsui Esperancini \\ Osmar de Carvalho Bueno ${ }^{2}$ Marli Dias Mascarenhas Oliveira ${ }^{3}$
}

\footnotetext{
${ }^{1}$ Agência Paulista de Tecnologia dos Agronegócios (APTA), Pólo Regional Leste Paulista de Monte Alegre do Sul, 13910-000, Monte Alegre do Sul, SP, Brasil. E-mail: patyturco@apta.sp.gov.br. "Corresponding author.

${ }^{2}$ Faculdade de Ciências Agronômicas (FCA), Universidade Estadual Paulista Julio de Mesquita Filho (UNESP), Botucatu, SP, Brasil.

${ }^{3}$ Agência Paulista de tecnologia dos Agronegócios, Instituto de Economia Agrícola (IEA), São Paulo, SP, Brasil.
}

\begin{abstract}
The objective of this study was to evaluate the economic benefit of coffee cultivation, with a focus on the distinction between conventional and irrigated coffee production systems. For the development of the study, the various productive systems were delineated from the data provided by a sample of producers to generate a matrix of average technical coefficients. The methodology used to estimate the operating cost of production is the one used by the Instituto de Economia Agricola (IEA). Profitability indicators were also evaluated. Results indicated that the effective operational cost (EOC) incurred in the irrigated production system is higher than that in the conventional system. As regards the cost composition, in the conventional coffee production system, the largest cost incurred is on fertilizers among all inputs, whereas in the irrigated production system, the largest cost incurred is on machinery and equipment that are mainly used in harvesting, for the period 2013-2015. Profitability index of the conventional coffee production system in 2015 was 44.8\%, and that of the drip irrigated production system was 49.7\%. In 2014, profitability rates were negative for both the conventional (-13.9\%) and irrigated coffee production systems (-8.6\%). The most preferable choice was found to be the irrigated production system, as it allows reducing the risk of loss in production during prolonged periods of water shortage as well as greater yields due to a larger production of grains.

Key words: production cost, regional coffee, economic comparative.
\end{abstract}

Rentabilidade econômica em sistemas de produção de café convencional e irrigado em três municípios da região de Marília, São Paulo

RESUMO: Este estudo teve como objetivo avaliar o beneficio econômico do cultivo de café, comparando os sistemas de café convencional e irrigado. Para o desenvolvimento do estudo, os sistemas produtivos foram delineados a partir de dados informados por uma amostra de produtores, para elaboração de uma matriz de coeficientes técnicos médios. A metodologia utilizada para a estimativa do custo operacional de produção é a do Instituto de Economia Agrícola (IEA) e foram avaliados indicadores de rentabilidade. Os resultados apontam que o custo operacional efetivo (COE) no sistema irrigado é maior do que no sistema convencional. Na composição do custo, no sistema de café convencional os maiores gastos foram com adubos no item insumos e, no sistema irrigado, os maiores dispêndios foram com máquinas e equipamentos principalmente com a colheita, nos anos de 2013, 2014 e 2015. O índice de lucratividade para o café convencional em 2015 foi de 44,8\% e para o sistema irrigado por gotejo em 49,7\%. No ano de 2014, os índices de lucratividade foram negativos tanto para o sistema de produção de café irrigado (- 8,6\%) como para o sistema de café convencional (-13,9\%). A melhor opção é o sistema irrigado, pois possibilita diminuir o risco de perda na produção em períodos prolongados de déficits hídricos além de possibilitar o maior rendimento com uma produção maior de grãos.

Palavras-chave: custo de produção, cafeicultura regional, comparativo econômico.

\section{INTRODUCTION}

After having been the main product of Brazilian exports for many years, coffee began to lose its relative importance, mainly due to the growth in the export of industrialized products (BLISKA et al., 2009). In 2015, coffee accounted for 7\% of Brazil's agribusiness exports, ranking fifth in the nation with a total revenue of US\$ 6.16 billion, which is equivalent to 37.1 million bags of $60 \mathrm{~kg}$ each (REIS, 2015).

According to the data from the Instituto de Economia Agrícola (IEA, 2017), coffee crops cover an area of 209.8 thousand hectares with an expected harvest of 4.3 million $60 \mathrm{~kg}$ bags in 2016-2017 in the state of São Paulo, which is the second largest coffee producing state in Brazil, accounting for $14.1 \%$ of the national production. 
Coffee production occupies the sixth position in the Valor da Produção Agrícola (VAP) in São Paulo, with a total value of $\mathrm{R} \$ 2.940$ billion in 2016 , a $61.6 \%$ increase from the previous year (SILVA et al., 2017). According to the author, average price received by state producers in 2016 was $\mathrm{R} \$ 484.36$ per $60 \mathrm{~kg}$ bag.

Fluctuation of the price of coffee bag and the gradual increase in the costs of chemical inputs are factors which have caused loss of profitability in coffee production in the recent years. In the last decade, new technologies and new processes have been introduced in the production process with an aim to avoid a decline in profitability by increasing the quality of grains and the productivity of coffee plantations.

Among the main periods of technological growth in coffee production, the period 1990-2000 witnessed a large increase in the use of irrigation, thus enabling cultivation of coffee in several regions of Brazil and boosting production in regions with water shortage.

In addition to the increase in the productivity, the use of irrigation systems can increase the efficiency and reduce the risks of input use, besides contributing towards a better quality of the drink, and reducing the risks of production losses (KARASAWA et al., 2002; MARTINS et al., 2007).

Therefore, the objective of this study was to conduct an economic analysis of the conventional and drip irrigation coffee production systems. This study contributed towards the understanding of productive dynamics, especially due to the distinct results of the analyses of these systems.

\section{MATERIALS AND METHODS}

Marília's Rural Development Office (RDO) is the third coffee producing region in the state of São Paulo, covering $12.5 \%$ or 24,552 hectares of the area. The estimated production for the agricultural year 2016-2017 is 519.5 thousand $60 \mathrm{~kg}$-bags (IEA, 2017). In 2015, the regional gross production value was R\$ 249 million (SILVA et al., 2016). In this study, five properties located in Marilia's RDO in the municipalities of Vera Cruz, Gália, and Garça were analysed (Table 1). A questionnaire for obtaining data regarding the production system was adopted. The field survey was carried out in the period 2012-2015.

Data were collected on the operations being carried out and the inputs used in each one of them, including agricultural machinery and the consumption of fuels, oils, lubricants, greases, gas, and electric energy. These technical coefficients were quantified with respect to the harvest in the period 2012-2015. Values of the physical quantities of the inputs refer to the average of the properties studied in their respective production systems for one hectare of the crop and the prices paid by the producer for the inputs, expressed in Reais.

Expenses of production cost were obtained with coffee growers or the service providers, when it is appropriate, thus effectively representing the value of the operations during the harvesting and postharvesting periods.

The concept used by MELLO et al. (1988) was adopted for the elaboration of the technical

Table 1 - Characteristics of conventional and irrigated coffee producers.

\begin{tabular}{|c|c|c|c|c|c|c|}
\hline \multirow{3}{*}{ Municipalities } & \multicolumn{5}{|c|}{-----------Total Area----------- } & \multirow{2}{*}{$\begin{array}{l}\text { Average } \\
\text { Plant } \mathrm{N}^{\mathrm{o}}\end{array}$} \\
\hline & Producer & Irrigated & Conventional & Spacing & Variety & \\
\hline & & ha & $\mathrm{Ha}$ & $\mathrm{m}$ & & ha \\
\hline \multirow{2}{*}{ Vera Cruz } & \multirow{2}{*}{1} & \multirow{2}{*}{120} & \multirow{2}{*}{-} & $3.80 \times 0.65$ & \multirow{2}{*}{ Obatã, Mundo Novo, Iapar } & \multirow{2}{*}{2,500 to 5,000} \\
\hline & & & & $3.30 \times 0.65$ & & \\
\hline \multirow{5}{*}{ Vera Cruz } & \multirow{4}{*}{2} & \multirow{4}{*}{46} & \multirow{4}{*}{64} & $4.00 \times 0.65$ & \multirow{4}{*}{$\begin{array}{l}\text { Mundo Novo, Icatu, Acaiá, } \\
\text { Iapar, Obatã, Ouro Verde }\end{array}$} & \multirow{4}{*}{2,500 to 5000} \\
\hline & & & & $3.50 \times 0.65$ & & \\
\hline & & & & $4.00 \times 2.00$ & & \\
\hline & & & & $3.30 \times 0.65$ & & \\
\hline & & & & $3.30 \times 0.65$ & Obatã & 2,500 to \\
\hline \multirow[t]{3}{*}{ Garça } & 3 & 90 & - & $4.00 \times 1.50$ & \multirow{3}{*}{$\begin{array}{l}\text { Mundo Novo, Ouro Verde, } \\
\text { Catuaí }\end{array}$} & \multirow{3}{*}{5,000} \\
\hline & & & & $4.00 \times 2.00$ & & \\
\hline & & & & $3.80 \times 2.50$ & & \\
\hline Garça & 4 & - & 50 & $3.50 \times 0.60$ & Icatu, Obatã & 4,000 \\
\hline Gália & 5 & & & $3.30 \times 0.65$ & Obatã, & 2,500 to \\
\hline \multirow[t]{2}{*}{ Gália } & 5 & 112 & 213 & $4.00 \times 1.50$ & \multirow{2}{*}{$\begin{array}{l}\text { Mundo Novo, Ouro Verde, } \\
\text { Catuaí, }\end{array}$} & \multirow{2}{*}{5,000} \\
\hline & & & & $3.80 \times 2.50$ & & \\
\hline
\end{tabular}

Ciência Rural, v.47, n.11, 2017. 
coefficient matrices of the production systems, which define a production system as the an amalgamation of management and agricultural techniques culturally carried out in a more or less homogeneous way by representative groups of producer.

MATSUNAGA et al. (1976) and MARTIN et al. (1998) developed a methodology for the estimation of the operational costs of production, where:

- Effective operational cost (EOC) is the cost incurred on machinery and equipment operations and labour and materials consumed throughout the production process; - Total operating cost (TOC) is the effective operating cost plus depreciation of machines, direct social charges ( $40 \%$ of the permanent labour cost), contribution to rural social security (CSSR) $(2.3 \%$ of the gross income), and interest at a rate of $8.75 \%$ per annum.

The linear depreciation method was adopted in this study, which computed the depreciation based on the initial value, duration, and final value of the good, as expressed by the formula below. $\mathrm{D}=(\mathrm{Vi}-\mathrm{Vf}) / \mathrm{n}$ where $\mathrm{D}$ is the depreciation per hour, $\mathrm{Vi}$ is the initial value (purchase price in R\$, regardless of the good being new or used), Vf is the final value (or scrap in $\mathrm{R} \$$ ), and $\mathrm{n}$ is the useful life in terms of number of hours.

Profitability indicators estimated in this study following MARTIN et al. (1998) were:

a) Gross Revenue (GR): The expected revenue per hectare for a predetermined sales price, given by $\mathrm{GR}=$ I X Up where GR is the gross income, I is the income per unit area (bag/ha), and Up is the unit price (R\$/bag); b) Operating profit (OP): The difference between the gross income and total operating cost (TOC) per hectare, given by $\mathrm{OP}=\mathrm{GR}-\mathrm{TOC}$ where $\mathrm{OP}$ is the operating profit, GR is the gross income, and TOC is the total operating cost.

The OP indicator measures the profitability of the activity in the short term, thus indicating the financial and operating conditions of the activity;

c) Profitability Index (PI): The ratio of operating profit to gross income as a percentage. It is an important measure of the profitability of agricultural activity, as it indicates the available rate of revenue generation, after the payment of all operating costs, charges, and so on, including depreciation. It is given by $\mathrm{PI}=(\mathrm{OP} / \mathrm{GR}){ }^{*} 100$ where PI is the profitability index, OP is the operating profit, and GR is the gross income.

\section{RESULTS AND DISCUSSION}

\section{Characterization of properties}

The surveyed properties have an average cultivated area of 140 hectares, which are divided into an average of 4.000 coffee plants per hectare. The most cultivated varieties of coffee are Obatã, Mundo Novo, and Ouro Verde. Selection of these varieties is based on the maturation time of the fruit, which is an important characteristic that facilitates the management of the harvest (GUERREIRO et al., 2006).

The spacings used are mostly around $4.00 \times 1.50 \mathrm{~m}$ and $3.30 \times 0.65 \mathrm{~m}$ in a semi-density system. Producers acquire certain inputs, such as fertilizers and pesticides at the market value of the day, in exchange of $60 \mathrm{~kg}$ bags of coffee benefited.

Both the production systems are characterized by techniques related to cultural practices, especially in the case of the irrigated production system during the harvesting and postharvesting periods.

\section{Production cost}

Total operational cost of conventional coffee production in 2012 was $\mathrm{R} \$ 8,230.80$, which is the lowest recorded value (Table 2). It rose to $\mathrm{R} \$$ $8,600.57$ in 2014 and peaked in 2015 at $\mathrm{R} \$ 10,248.16$. Input items in the total operational cost indicated the highest amount disbursed by the producer. Among them, fertilizers and micronutrients comprised the largest share of the effective operating costs in the four study periods. The use of machines and equipment in the conventional system was the second most important item in terms of disbursement made by the producers.

Effective operating costs in the irrigated production system (Table 3 ) indicated that the use of machines and equipment for harvesting was the most expensive item in the four study periods, followed by fertilizers. The highest value, $\mathrm{R} \$ 11,934.48$, was recorded in 2015. In 2014, the total operating cost was $\mathrm{R} \$ 11,732.52$. Thus, the irrigated production system indicated a decrease in production. The lowest cost in the four years of the study was observed in 2013.

By comparing the two production systems, it can be observed that the cost of labour in the period 2012-2015 was the lowest in the conventional production system, while it was relatively higher in the irrigated production system. Harvesting is the most costly phase of both systems.

By analysing the percentage composition of effective operating costs (Figure 1), it can be verified that the share of costs incurred on machines and equipment, which is above $41 \%$, was higher in the irrigated production system in all the four study periods, even when it fell in 2012. The second most expensive item in the irrigated production system is the inputs, which accounts for more than $35 \%$ in all four the study periods. 
Table 2 - Estimated total operational cost by energy category in $\mathrm{R} \$ \mathrm{ha}^{-1}$ on the conventional coffee production system.

\begin{tabular}{|c|c|c|c|c|}
\hline Specifications & Year 2012 & Year 2013 & Year 2014 & Year 2015 \\
\hline Labour & 338.88 & 414.55 & 454.93 & 464.24 \\
\hline Fuels & 102.22 & 108.42 & 77.76 & 152.88 \\
\hline \multirow{2}{*}{\multicolumn{5}{|c|}{$\begin{array}{lccc}\text { Cultivation } & 796.13 & 933.39 & 940.15\end{array}$}} \\
\hline & & & & \\
\hline Harvest & $1,348.69$ & $1,436.75$ & $1,580.58$ & $1,537.7$ \\
\hline Post-harvest & 164.56 & 175.05 & 143.41 & 232.70 \\
\hline \multicolumn{5}{|c|}{ 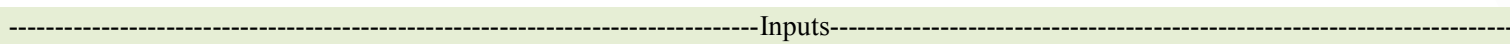 } \\
\hline Soil correctives & 104.58 & 196.94 & 88.20 & 227.00 \\
\hline Fertilizers and micronutrients & $3,884.98$ & $3,110.50$ & $3,855.00$ & $4,288.40$ \\
\hline Pesticides & 766.28 & $1,092.04$ & 776.06 & $1,379.95$ \\
\hline Soil analysis & 30.00 & 32.00 & 36.00 & 40.00 \\
\hline Dryer gas & 13.04 & 15.32 & 14.01 & 16.48 \\
\hline Effective operational cost (EOC) & $7,549.36$ & $7,523.96$ & $7,966.22$ & $9,309.22$ \\
\hline Social security contribution ${ }^{1}$ & 281.24 & 315.48 & 173.56 & 427.43 \\
\hline Payroll charges $^{2}$ & 135.55 & 165.82 & 181.97 & 185.69 \\
\hline Financial charges $^{3}$ & 264.23 & 263.37 & 278.82 & 325.82 \\
\hline TOTAL (TOC) & $8,230.80$ & $8,267.63$ & $8,600.57$ & $10,248.16$ \\
\hline
\end{tabular}

Source: Search data.

${ }^{1}$ Contribution of rural social security $(2.3 \%$ of gross income).

${ }^{2}$ Payroll charges $(40 \%)^{3}$ Financial charges $(8.75 \%)$.

In conventional coffee production system, expenses on fertilizers and micronutrients required the largest disbursements by the producer. The share of this cost was over $51 \%$ of the effective operating cost in 2012, while it was above $41 \%$ in the other analyzed years of the study period. Cost of machines and equipment accounted for over $29 \%$ in all periods. Another item, pesticides, accounted for a large share in the conventional production system vis-à-vis the irrigated production system.

Although, the cost of implementing an irrigation system is high, its maintenance and use do not make up a significant share of the production cost. Costs incurred on irrigation include the consumption of electricity and labour, the hourly cost of hydraulic pumps, as well as the grant fee of $\mathrm{R} \$ 100.70$ paid by the producers every year. Its highest share in production cost was $4 \%$ in 2015 , while its lowest share was $2.3 \%$ in 2013 (Figure 1). Irrigation, together with soluble and micronutrient fertilizers in water, induced an average productivity increase of 10.4 $60 \mathrm{~kg}$ coffee bags as compared to the conventional coffee production in the period 2012-2015.

The use of drip irrigation along with fertilizers leads to the best use of nutrients by plants, thus favouring the development of their productive potential, which boosts productivity in turn.

\section{Profitability}

The analysis of the profitability indicators for coffee cultivation (Table 4), that is, the technologies, productivity gained, and prices received, were positive for both systems in 2012, 2013, and 2015 , thus presenting gross income which provides the remuneration of the incurred costs. Values of the operating profit and the profitability index obtained indicated a margin that can compensate for other costs that are not accounted for in this analysis, such as the producer's remuneration.

The gross revenue generated in 2014 was not sufficient to cover all the expenses incurred in the production process. Negative values of operating profit and profitability index of the current year indicate that, in addition to not covering the aforementioned costs, profits do not present a positive margin to cover other production costs. Low values are related to the price of the $60 \mathrm{~kg}$ coffee bag, which was lower during that year in comparison to other years. These low values are linked to the classification obtained by the coffee sample of the producers who were surveyed.

Gross revenues of 2015 were higher in the case of the irrigated production system, reaching $\mathrm{R} \$$ $23,523.19$, while the conventional system reached $\mathrm{R} \$$ 18,584.34. The best profitability index was recorded 
Table 3 - Estimated total operating cost by energy category in $\mathrm{R} \$ \mathrm{ha}^{-1}$ on the irrigated coffee production system.

\begin{tabular}{|c|c|c|c|c|}
\hline Specifications & Year 2012 & Year 2013 & Year 2014 & Year 2015 \\
\hline Labour & 565.65 & 615.82 & 718.37 & 804.44 \\
\hline Fuels & 75.32 & 108.42 & 112.32 & 121.68 \\
\hline \multicolumn{5}{|c|}{-------------------------------------------------------------------------Machines and equipment-------------------------------------------------------- } \\
\hline Cultivation & 859.70 & 93.80 & $1,021.93$ & 958.78 \\
\hline Harvest & $3,009.4$ & $3,244.75$ & $3,562.43$ & $3,326.18$ \\
\hline Post-harvest & 83.33 & 126.42 & 132.59 & 260.65 \\
\hline \multicolumn{5}{|c|}{ } \\
\hline Soil correctives & 192.00 & 164.76 & 95.00 & 310.00 \\
\hline Fertilizers and micronutrients & $3,849.03$ & $3,301.52$ & $4,058.51$ & $3,729.04$ \\
\hline Pesticides & 735.95 & 714.70 & 724.93 & 703.49 \\
\hline Soil analysis & 30.00 & 32.00 & 36.00 & 40.00 \\
\hline Irrigation system & 157.10 & 115.52 & 242.56 & 322.89 \\
\hline Dryer gas & 15.25 & 15.98 & 14.01 & 19.43 \\
\hline Grant fee & 100.70 & 100.70 & 100.70 & 100.70 \\
\hline Effective operational cost (EOC) & $9,673.37$ & $9,474.39$ & $10,820.35$ & $10,697.28$ \\
\hline Social security contribution ${ }^{1}$ & 374.34 & 358.85 & 246.12 & 541.03 \\
\hline Payroll charges $^{2}$ & 226.26 & 245.92 & 287.34 & 321.77 \\
\hline Financial charges $^{3}$ & 338.57 & 331.60 & 378.71 & 374.40 \\
\hline Total Operating Cost (TOC) & $10,612.54$ & $10,410.76$ & $11,732.52$ & $11,934.48$ \\
\hline
\end{tabular}

${ }^{1}$ Contribution of rural social security $(2.3 \%$ of gross income).

${ }^{2}$ Payroll charges $(40 \%)^{3}$ Financial charges $(8.75 \%)$.

in 2015 , which was $49.7 \%$ for the irrigated production system and $44.8 \%$ for the conventional system. Losses occurred in 2014 due to the drought that was accompanied by low production, were the main reason for the low economic performance of both systems and the lower price per $60 \mathrm{~kg}$ bag faced by the producer.

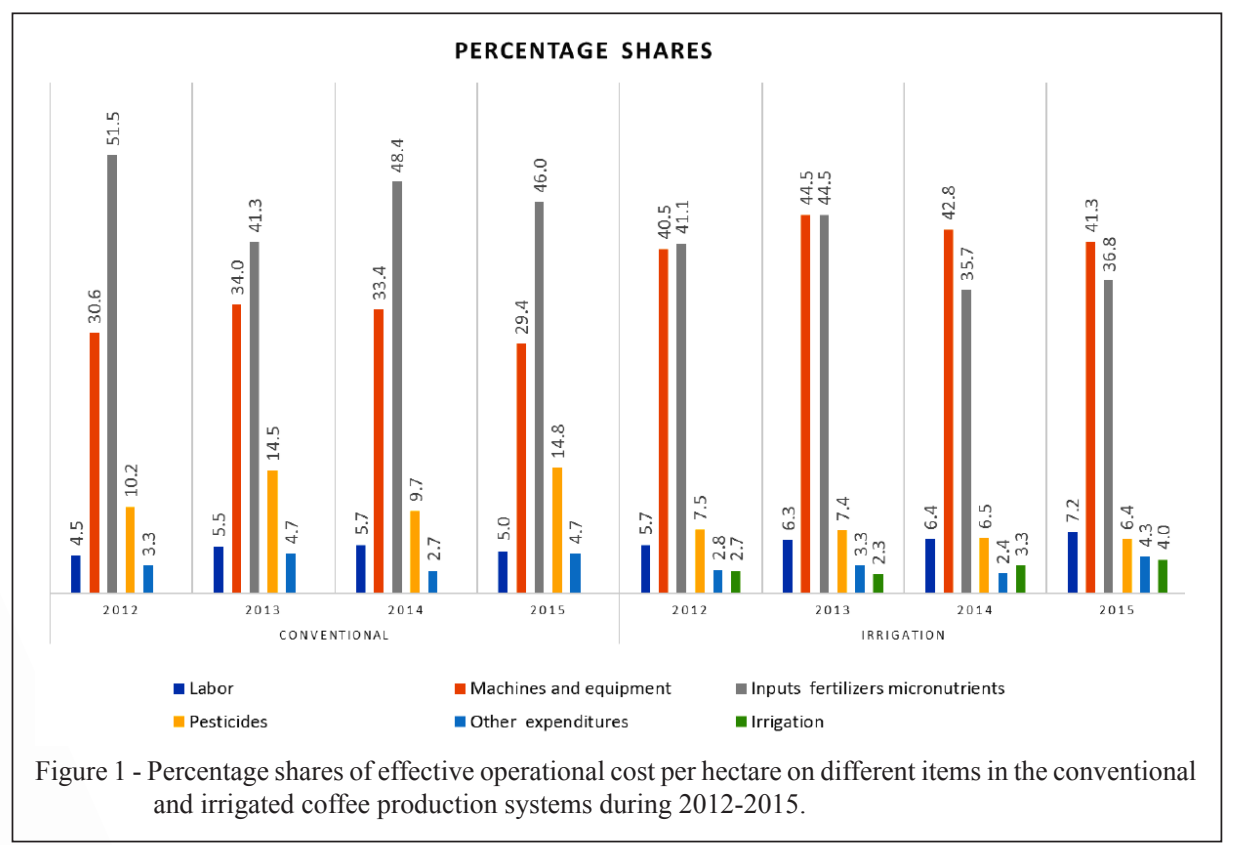

Ciência Rural, v.47, n.11, 2017. 
Table 4 - Profitability the conventional and irrigated coffee production systems in the municipalities of Gália, Garça and Vera Cruz during 2012-2015.

\begin{tabular}{|c|c|c|c|c|c|c|}
\hline & Years & $\begin{array}{c}\text { Average Price } \\
\text { Received }\end{array}$ & $\begin{array}{c}\text { Productivity } \\
\left(\text { bag } 60 \mathrm{~kg}^{-1} \mathrm{ha}^{-1} \text { ) }\right.\end{array}$ & Gross Income & Operating Profit & $\begin{array}{l}\text { Profitability } \\
\text { Index }\end{array}$ \\
\hline & & $\mathrm{R} \$$ & & $\mathrm{R} \$ \mathrm{ha}^{-1}$ & $\mathrm{R} \$ \mathrm{ha}^{-1}$ & $\%$ \\
\hline \multirow{4}{*}{ Conventional } & 2012 & 426.07 & 28.7 & $12,228.20$ & $3,997.40$ & 32.6 \\
\hline & 2013 & 369.72 & 37.1 & $13,716.12$ & $5,448.49$ & 39.7 \\
\hline & 2014 & 309.28 & 24.4 & $7,546.43$ & $-1,054.14$ & -13.9 \\
\hline & 2015 & 509.16 & 36.5 & $18,584.34$ & $8,336.18$ & 44.8 \\
\hline \multirow{4}{*}{ Irrigation } & 2012 & 426.07 & 38.2 & $16,275.87$ & $5,663.03$ & 34.7 \\
\hline & 2013 & 369.72 & 42.2 & $15,602.18$ & $5,191.42$ & 33.2 \\
\hline & 2014 & 309.28 & 34.6 & $10,701.08$ & -1031.44 & -8.6 \\
\hline & 2015 & 509.16 & 46.2 & $23,523.19$ & $11,588.71$ & 49.7 \\
\hline
\end{tabular}

Source: Search data.

However, these data need to be carefully analyzed, as prices faced by farmers in 2013 and 2014 were lower than those in 2012 and 2015. The severe drought of 2014 led to the rise in the price of coffee, which is determined in the international market, in 2015.

A study by SCALCO et al. (2012) gave supports to the research data, which indicated that the use of an irrigation system increases the production of coffee, which in turn increased profitability.

\section{CONCLUSION}

The best option for the producers of the studied region is the drip irrigation system, as it reduces the risks of production loss in prolonged periods of water shortage and ensures a higher yield of grains.

Analysis of economic indicators verified that the costs with on inputs, which accounted for $34.5 \%$ of the production costs, encumbered the conventional coffee production system the most. This is followed by the use of machines and equipment, which accounted for $29.1 \%$ of the production costs, and the use of pesticides at $11.2 \%$. As regards the irrigated production system, the items with the highest share in the production costs were machines and equipment used mainly for harvesting, which accounted for $39.5 \%$, followed by inputs, which accounted for $35.4 \%$.

Analysis of the production costs also revealed that the use of an irrigation system does not increase the costs incurred on coffee production, besides the initial cost. The use of this technology can mitigate production risks related to water shortage, such as the drought of 2014.
Evaluation of the profitability indicators indicated that the operating profit and the profitability index were negative in 2014 in both the systems, with the irrigated production system indicating relatively lower figures. The irrigated production system indicated a higher production than the conventional system in the following harvest, thus indicating better recovery due to the use of irrigation and fertigation.

Gross revenues of both the systems in 2015 were higher. It should be noted that the 2015 prices, determined on the basis of the international market, incorporated the fall in production resulting from the severe drought that occurred in 2014, thus leading to a better remuneration for the producer.

These results are limited to the producers who were studied. Results of the economic analyses vary greatly with the production units. Regionally, beyond the individual characteristics, edaphoclimatic conditions, altitude, and variety adaptation, among other variables, play a role as well. Further, economic analysis provides management with strategic information, greatly underpinning its usefulness in coffee farms.

\section{REFERENCES}

BLISKA, F.M.M. et al. Phytotechnical, social and economic dynamics of coffee farming in Brazil Informações Econômicas, São Paulo, v.39, n.1, p.5 - 18, 2009. Available from:<file:///C:/Users/ Patricia\%20Turco/Downloads/DINAMICA-FITOTECNICA $\% 20$ (1).pdf $>$. Accessed: Jan. 27, 2016.

GUERREIRO FILHO, O. et al. Characterization of Coffea Arabica cultivars by minimum descriptors. INFOBIBOS [online], 2006. Available from: <http://www.infobibos.com/Artigos/2006_2/ Cultivares_cafe/Index.htm>. Accessed: May 12, 2016. 
INSTITUTO DE ECONOMIAAGRÍCOLA(IEA). Banco de dados IEA. Available from: $<$ http://www.iea.sp.gov.br/out/bancodedados. html>. Accessed: May 12, 2017.

KARASAWA, S. et al. Response of cv. Topázio MG-1190 coffee submitted to different periods of irrigation. Revista Brasileira de Engenharia Agrícola e Ambiental, Campina Grande, v.6, n.1, p.28-34, 2002. Available from: <http://www.scielo.br/scielo. php? script $=$ sci_arttext\&pid $=$ S1415-43662002000100006 $>$. Accessed: Feb. 24, 2016.

MARTIN, N.B. et al. Integrated farm costs system - CUSTAGRI - Informações Econômicas, São Paulo, v.28, n.1, p.7-28, 1998. Available from: <http://www.iea.sp.gov.br/ftpiea/ie/1998/tec1-0198. pdf>. Accessed: Mar. 3, 2016.

MARTINS, C.C. et al. Drip irrigation management on coffe crop (Coffea arabica L.). Bioscience Journal, Uberlândia (MG). v.23, n.2 p.61-69. 2007. Available from: <http://www.seer.ufu.br/index.php/ biosciencejournal/article/viewFile/6627/4355>. Accessed: Nov. 26, 2016.

MATSUNAGA, M. et al. Cost of production methodology utilized by the IEA. Agricultura em São Paulo, São Paulo, v.23, n.1, p.123-139, 1976. Available from: <http://www.iea.sp.gov.br/ftpiea/rea/tomo1_76 artigo3.pdf>. Accessed: Nov. 24, 2016.

MELLO, N.T.C. de et al. Proposal for a new production cost methodology of the Institute of Agricultural Economics São Paulo:
SAA/IEA, 1988. 13p. (Relatório de Pesquisa, 14/88). Available from: $<$ http://www.iea.sp.gov.br/out/TerTexto.php?codTexto=10706>. Accessed: Abr. 12, 2016.

REIS, K.M. dos. Coffee: Production and values payments to the producer in Brazil from 2001 to 2015. In: SIMPÓSIO BRASILEIRO DE PESQUISA EM CAFEICULTURA IRRIGADA, 18., 2015, Araguari. Anais... Araguari: Embrapa informações Tecnológicas, 2015. p.18. Available from: $<$ http://docplayer.com br/25001128-Cafe-producao-e-valores-pagos-ao-produtor-nobrasil-de-2001-a-2015.html>. Accessed: May. 30, 2016.

SCALCO, M.S. et al. Irrigated and non-irrigated coffee (Coffea Arabica Ll.) under super dense conditions Coffee Science, Lavras, v.6, n.3, p 193-202, 2011. ISSN 1984-3909. Available from: $<$ http:/www.coffeescience.ufla.br/index.php/coffeescience/article/ view/465>. Accessed: Nov. 22, 2015.

SILVA, J.R. da et al. Evolution of the value of Agricultural production in São Paulo by administrative region, 1995 - 2015. Análises e Indicadores do Agronegócio, v.11, n.11, p.1, 2016. Available from: <http://www.iea.sp.gov.br/out/LerTexto. php?codTexto=14201>. Accessed: Jan. 2017.

SILVA J.R. et al. Value of agricultural production in the State of São Paulo: final result 2016. Análises e Indicadores do Agronegócio, v.12, n.4, p.1, 2017. Available from: <http://www.iea.sp.gov.br/ ftpiea/AIA/AIA-75-2016.pdf>. Accessed: May 2017. 